\title{
The Present Situation and Solution to the Graduation Design of Applied Undergraduates
}

\author{
Hua Ren \\ (Xi 'an FanyiUniversity, Xi 'an Shaanxi,710105,China) \\ 80899050@qq.com
}

Keywords: Application-oriented; Graduation Design; Reform Strategy

\begin{abstract}
Talents are the "products" of colleges and universities, and the overall improvement of the quality of talents is the starting point and foothold of all work in the institutions. Graduation design is an important sub-project in practical teaching for applied higher engineering education system. It's also a crucial teaching procedure to train students' applied knowledge, cultivate ability and creative thinking, and improve the quality. The quality of graduation design is an important basis for measuring teaching level, students' graduation and degree qualification, and the quality of graduation design directly influences the school's reputation. Taking Xi 'an Fanyi University as an example, this paper puts forward corresponding solutions to the current situation of the graduate design of applied undergraduates.
\end{abstract}

\section{Introduction}

In training applied undergraduate to seek for truth, strengthening social consciousness, conducting basic training for scientific research, improving the comprehensive practical ability and comprehensive quality, etc., graduation design plays an irreplaceable role. It is an important manifestation for combining education with productive labor and social practice, also it's a critical practice step to cultivate applied college students' innovation ability, practical ability and entrepreneurial spirit. Due to the update speed of professional knowledge for science and technology majors, they spent a lot of time in learning professional knowledge, while they are likely to be eliminated slowly after graduation. Students should not only keep up with the trend of technical updates, but also to combine the existing knowledge with real application to solve practical problems, and they will face great challenge after graduation. Therefore, the graduation design is a very important practical teaching link for applied colleges and universities in the process of teaching, which is to train students' applied knowledge, cultivate ability and creative thinking, and improve the quality of students. Also it's the breakthrough for building the characteristics of applied higher education.

\section{Current Situation of Graduation Design for Applied Undergraduates}

In recent years, in order to survive and expand enrollment, private colleges and universities inevitably lead to the shortage of teachers. But according to the requirements of students-faculty ratio by the ministry of education, the schools have to recruit fresh graduates with high education to make up for the students-faculty ratio. These highly educated teachers graduated from their Alma mater to teach in new schools. On the one hand, they have no comprehensive practical experience of larger projects, while on the other hand, they are still learning basic teaching skills. In addition, the full-time teachers of private colleges and universities have an average teaching task of 400 hours per year, so they don't have much energy to guide the graduation design in the face of such a large amount of teaching time. The titles of these teachers are intermediate or above, and they are usually assigned too many teaching task. For most of the time, they are preparing the class, otherwise giving lessons. This will inevitably lead to serious decline in the quality of graduation design guidance. This paper analyzes the existing problems in the graduation design among applied undergraduates.

(1)Instruct teachers are short of practical experience; 
(2)Topic selection is improper and lack of innovation;

(3)Management is not effective and the process of graduation defense exists in name only.

In view of the above problems, the reform of undergraduate graduation design in application-oriented colleges is like an arrow in the bow. It is definitely necessary to research how to reform to improve the quality of the undergraduate graduation design in applied colleges, and how to make it cultivate the talents for the need to serve local economic and social development, which is the current problems we need every teacher to face and solve.

\section{Strategies to Solve the Problems about Graduation Design of Applied Undergraduates}

In view of the above three problems in the graduation design of applied undergraduates, the research group considers that the current situation of applied undergraduates' graduation design is not optimistic, and the reform is urgent. Therefore, the research drew lessons from the similar private colleges for their long-term experience in the graduation design, as well as years of experience in graduation design management and practice guidance among team members, putting forward the following reform solutions to applied undergraduate graduation design.

Setting up the Graduation Design Guidance Team. In the process of applied undergraduate graduation design guidance, the research group formed guiding team according to professional direction, and the team matches the teachers who have practical project experience with young teachers. Each team hired one engineer with higher technical level from enterprises to provide auxiliary guide. The team guidance mechanism is implemented to ensure the guidance time and make up the gap between graduation design and actual social needs. At the same time, it can complement the problem of poor quality of graduation design due to the teacher's narrow research. It also enables teachers to learn from each other, improve each other and make progress together.

Reforming the Original Model of Graduation Design. The topic of graduation design not only determines the scope and goal of scientific practice, but also determines its content and method. Therefore, the topic of graduation design should follow three principles.

(1) meet the requirements of professional training objectives; (2) embody the principle of combining theory and practice; (3) choose topic with moderate difficulty.

Based on the existing methods of selecting graduation design topic, the research group has carried out a large number of reforms. The original mode of graduation design topic selection was reformed by increasing topics from the production practice, actual project from the enterprise production, and also the graduation design on the basis of college students' innovative entrepreneurial training project. A few instructors give students part of their project module as graduation design topic. These reforms completely avoid the topic being only a mere talking.

Establishing a Graduation Design Website and Carrying out Repeat Rate Testing. An information website for the application-oriented undergraduate design will be established, which will mainly introduces the various guidance about specification and document of graduation design writing, design information searching, information announcement, topic selection, questionnaire investigation, BBS etc. to provide the advantageous tool for graduation design work. And the purpose is to reflect the project characteristic of the service.

In order to show the originality of the thesis, the reform of the research require each student's graduation thesis to be tested by a database of China National Knowledge Infrastructure (CNKI), and the repeat rate within $30 \%$ can be regarded as passing through the test.

Standardize the Defense of Graduation Design. The plan for the reform of the research group is that the guide teacher of the graduation design is not allowed to be a judge in the defense group, nor to be a reviewer of the design. In addition, before graduation design defense, each defense team must carry on a strict inspection according to the graduation design qualification requirements to check the quality and repeat rate of the graduation thesis, and also the qualification to take part in the defense. For those who passed the requirements, a defense permit will be issued. For those who failed, the permit will be delayed until qualification is granted again. 


\section{Summary}

(1) The construction of teacher team directly influences the graduation design level of applied undergraduates. Therefore, colleges and universities should constantly introduce teachers, improve the structure of teachers and strengthen the construction of teachers' team practice, so as to guarantee the overall quality of the graduation design of new undergraduates.

(2) In order to improve the quality of graduation design, colleges and universities must start from the fundamental problem, that is to improve the awareness and thought of the students and instructors as well, to cultivate the guide teachers and make them love education career wholeheartedly and dedicate themselves to the cause of education. Meanwhile, guide teachers should make students feel the usefulness and value of the graduation design and stimulate their initiative.

(3) The traditional way of graduation design inspection need to be changed, and the research group suggest to increase the frequency of inspection. The staff of teaching management should examine and accept the work strictly, and those students with poor performance will enter into the second round defense. This can promote the quality of graduation design.

(4) strengthen the monitoring management step by step to improve the efficiency of management

Graduation design is an important part in cultivating applied undergraduate education.Only setting up perfect and effective quality supervision system, can ensure the quality of undergraduate course graduation design.If there is no a complete set of graduation design guide, review and defense the system institutional constraints, undergraduate course graduation design for college students will be able to smooth degree certificate or not has lost the most basic binding, The assessment function of undergraduate graduation design is not really played .Design a set of scientific and reasonable undergraduate course graduation design quality tracking and monitoring system, including students' writing, teachers'guidance and college management three levels of monitoring.With practical and feasible measures to reverse the style is not straight, ethics is not high, study trends of the discipline is lax.Additionally, random sample undergraduate graduation design, if it finds it is not comply with the rules and regulations in selectiving examination, it will not give a defense pass, you will not be able to defend yourself until you have passed.

(5) make graduation design question-and-answer session and summarized

Graduation design defense is an important form of evaluating the designing level of graduation design and review the design level of graduation design and students' knowledge level, and it is the key link in the process of graduation design, mainly by the form of students' explanation and answering questions, evaluating the academic level of graduation design, students' presentation communication skills, the basic level of knowledege,application degree and defense situation are a necessary complement of faculty adviser and reviewing teacher's graduation design. it can further investigate graduation design the authors' understanding of the graduation design degree, the breadth and depth of professional knowledge.Through the graduation design defense, students can publish their opinions or put forward to constructive suggestions, and improve the ability of oral communication.

After the research team summarized and verified undergraduates for two grades, it is proved that the reform has its effects, but it must be practical and realistic according to different types of schools, different majors and even different individuality of students; For application-oriented universities, the target orientation of talent training is directed to cultivate talents for the basic level and the first production line. So it is particularly important to carry out graduation design among these students. From the topic selection, opening, process guidance, intermediate inspection, graduation design defense etc., we need to manage and supervise strictly. And also there is a necessity for the graduation design (paper) to go through a blind review. Applied undergraduate graduation design process is a very complicated system engineering, it involves all aspects, such as enterprises and public institutions, colleges and students, the cultivation of applied undergraduate, theory related to practice closely and obtaining the basic training of the engineer are the most important link, especially the quality of graduation design is often a measure of students' in higher 
education, teaching effectiveness and the level of educational institutions in applied universities

\section{Acknowledgements}

Fund Project: "Study on Graduation Design Reform of Applied Undergraduate" (Project No. : SGH140890) of education science planning project in Shaanxi province

Fund Project: "Web Programming Class Teaching Team" project built by Xi 'an Fanyi University teaching team (project No. : Z1312)

\section{References}

[1] Ren Xiaoming \& Liu Jun. Applied Undergraduate Graduation Design Reform and the Practice Exploration. China's Electricity Education. 2014 (36) (In Chinese)

[2] Xu Zhi. On Teaching Reform about Graduation Design for Engineering Majors. University Education. 2015 (05) (In Chinese)

[3] Wu Yifeng, Zhang Shuming, Tian Xia. The Reform and Practice to Improve the Quality of Undergraduate Graduation Design (paper) in Shanghai Jiao Tong University. Experimental Technology and Management. 2014 (7) (In Chinese) 